\title{
FONDASI ETIKA EKOLOGI DARI PERSPEKTIF TEOLOGI KRISTEN
}

\author{
Anita Y. Tomusu ${ }^{1}$ \\ Sekolah Tinggi Teologi Sabda Agung \\ anitatomusu24@gmail.com
}

\begin{abstract}
Ecological Ethics must have a solid foundation from the perspective of Christian Theology. So that every believer understands the theological basis of truth in their behavior towards the nature around them. Nature around humans is in critical condition from time to time. This condition is further exacerbated by the lack of human understanding of the reasons and how to behave and act to protect and preserve the surrounding environment. Christian theological foundations are formulated to provide the understanding and shape new attitudes and behaviors of Christians with God as creator and the environment in which they live. Thus, there will be a harmonious relationship between humans and other creations for the sake survival along on earth.
\end{abstract}

Keywords: Foundations, Ecological Ethics, Christian Theology

\begin{abstract}
Abstrak
Etika Ekologi harus memiliki fondasi yang kokoh dari perspektif teologi Kristen. Agar setiap orang percaya memahami dasar kebenaran secara teologis perilaku mereka terhadap alam di sekitarnya. Alam sekitar manusia berada dalam kondisi kritis dari waktu ke waktu. Kondisi ini semakin diperparah karena kurangnya pemahaman manusia tentang alasan dan bagaimana harus bersikap dan bertindak menjaga dan melestarikan lingkungannya. Fondasi teologis Kristen dirumuskan dengan tujuan untuk memberikan pemahaman dan membentuk sikap serta perilaku baru orang Kristen dalam hubungannya dengan Allah sebagai Pencipta dan alam sekitar dimana ia tinggal. Dengan demikian, akan terjalin hubungan yang harmonis di antara manusia dan ciptaan lainnya demi keberlangsungan hidup bersama di bumi.
\end{abstract}

Kata Kunci: Fondasi, Etika Ekologi, Teologi Kristen

\section{PENDAHULUAN}

Di zaman ini, dimana manusia semakin bertambah banyak. Kesulitan dan permasalahan hidup yang ada semakin kompleks. Angka kemiskinan yang terus bertambah. Kebutuhan hidup yang semakin banyak, Manusia semakin sulit mengendalikan diri karena

\footnotetext{
${ }^{1}$ Dosen Tetap Prodi S1 Teologi STT Sabda Agung, Jabatan: Ketua Pusat Penjaminan Mutu STTSA Pengampu Mata Kuliah: Pengantar Perjanjian Lama dan Hermeneutik
} 
terdesak oleh kebutuhan dan sikap serakah manusia yang tidak pernah puas. Manusia seakanakan tidak punya pilihan lain selain mengeruk sumber daya alam sebanyak-banyak, membakar hutan untuk kepentingan sendiri, melakukan pencemaran, membuang sampah di sungai dan perbuatan lainnya yang merusak alam. Belum lagi kemajuan teknologi yang tidak berimbang dengan pengawasan lingkungan yang tidak ketat, telah menghantar alam pada situasi yang terpojok. Manusia modern menghadapi alam hampir tanpa menggunakan "hati nurani”. Alam begitu saja dieksploitasi dan dicemari tanpa rasa bersalah atau rasa risih, tidak punya rasa segan atau hormat. Sikap seperti ini merupakan produk rasionalisasi manusia yang menghadapi segala sesuatu secara rasional saja. ${ }^{2}$ Rasio yang bicara, hati nurani yang diam. Manusia telah menyelewengkan "superioritas" untuk kepentingan manusia semata. Manusia tidak lagi menghormati Allah sebagai Pencipta dan Pemilik alam semesta. Alam semakin merana dan terpojok oleh sikap manusia yang sewenang-wenang. Namun, di sisi lain manusia dapat merasakan akibat dari tindakannya, dimana bencana alam lebih sering terjadi dan begitu banyak mendatangkan kesusahan dan penderitaan. Bencana banjir merupakan bencana yang sering terjadi. Banyak jiwa yang melayang dan harta benda yang hancur. Aida Greenbury, juru kampanye dan penasihat 'zero deforestation' asal Indonesia yang berbasis di Sydney, mengatakan dalam kurun waktu 30 tahun banjir merupakan bencana yang terjadi di Indonesia, termasuk pulau Kalimantan. Hal ini diakibatkan terjadinya perubahan fungsi lahan dan hutan menjadi tempat pertambangan dan perkebunan kelapa sawit. Penebangan hutan menjadi penyebab emisi tinggi saat ini. ${ }^{3}$

Jika hal ini terus dibiarkan manusia dan alam akan sama-sama rusak. Yang dibutuhkan adalah penegakkan hukum yang tegas, pengawasan yang terpadu, upaya pelestarian yang intens, pertobatan yang radikal dari sikap destruktif. Selain itu diperlukan pemulihan hubungan antara manusia dan alam semesta. Robert P. Borong mengatakan: "kita perlu menata hubungan baru dengan alam dalam bentuk sikap yang semakin mendekatkan kita dengan alam dan menimbulkan rasa syukur serta rasa cukup dan puas dari apa yang dapat kita nikmati dari alam."4 Hubungan yang baru dengan alam semesta dapat menyelaraskan kembali sistem yang ada di alam semesta yang saling menopang. Untuk melaksanakan penatalayanan lingkungan hidup, diperlukan fondasi dasar yang kokoh yang

\footnotetext{
${ }^{2}$ Robert P Porong, Etika Bumi Baru, 1st ed. (Jakarta: BPK Gunung Mulia, 2003). 2

${ }^{3}$ https://news.detik.com/abc-australia/d-5345080/indonesia-alami-185-bencana-di-awal-2021-jadiperingatan-soal-kerusakan-alam

${ }^{4}$ Ibid. 148
} 
menjadi tempat untuk berpijak untuk menentukan sikap dan tindakan etis Kristen yang dapat mengatur hubungan manusia dengan alam sekitarnya.

\section{METODE}

Penelitian bertujuan menemukan fondasi teologis etika ekologi berdasarkan iman Kristen yang nantinya menjadi landasan yang kokoh bagi terciptanya sikap dan perilaku yang baru orang percaya. Penelitian ini adalah penelitian kualitatif dengan melakukan kajian terhadap teks Alkitab sebagai landasan utama dan literatur yang terkait lainnya. Hasil temuan diuraikan secara deskriptif untuk memberi gambaran yang utuh dari dasar etika ekologi dari perspektif teologi Kristen.

\section{HASIL DAN PEMBAHASAN}

Mandat Allah Kejadian 1:28 "beranakcuculah, penuhilah bumi, taklukkan dan berkuasa atas ciptaan lain", kemudian dalam Kejadian 2:15 "mengusahakan dan memelihara" taman Eden, yang diberikan kepada manusia harus dilaksanakan sesuai dengan tujuan penciptaan. Mandat Allah menjadi fondasi utama atau dasar teologis etika ekologi Kristen. Allah yang adalah pencipta, Pemilik, Pemegang, kekuasaan tertinggi di alam semesta memberikan mandat yang harus dijalankan oleh manusia. Allah berhak mengatur segala sesuatu menurut kehendakNya. Kedaulatan Allah atas setiap mahkluk adalah mutlak. Berdasarkan hal tersebut etika ekologi Kristen yang dihasilkan adalah sebagai berikut:

1. Sikap Etis Ekologi Kristen
a. Menghormati Allah Pencipta Alam Semesta
b. Melakukan Tugas Penatalayanan Atas Alam Semesta
c. Menghargai Mahkluk hidup Di Alam Semesta

2. Tindakan Etis Ekologi Kristen
a. Tindakan Evaluatif
b. Tindakan Preventif
c. Tindakan Rehabilitasi
d. Tindakan Kerja Sama

Secara umum, arti etika dalam Kamus Besar Bahasa Indonesia adalah ilmu tentang apa yang baik dan apa yang buruk dan tentang hak dan kewajiban moral (akhlak). ${ }^{5}$ J.

\footnotetext{
${ }^{5}$ Tim Penyusun, "Kamus Besar Bahasa Indonesia," in Kamus, 2nd ed. (Jakarta: Badan Pengembangan dan Pembinaan Bahasa Kementerian Pendidikan dan Kebudayaan Republik Indonesia, 2016), 271 
Verkuyl menambahkan bahwa etika adalah ilmu pengetahuan normatif yang memajukan apa yang baik. Menurut hukum Taurat dan Injil apa yang baik itu adalah segala yang dikehendaki Allah, itulah yang baik, ${ }^{6}$ Robert P. Borong memberikan defenisi etika adalah uraian bagaimana seseorang memperlakukan yang lain yang adalah cerminan kebenaran dan kebaikan dirinya, dilain sisi menyatakan norma keadilan, kebenaran dan kasih terhadap sesama. $^{7}$

Arti "Ekologi" dalam Kamus Besar Bahasa Indonesia adalah: "ilmu mengenai hubungan timbal balik antara makhluk hidup dan (kondisi) alam sekitarnya (lingkungannya). ${ }^{8}$ Istilah ekologi pertama kali dimunculkan oleh Ernst Haeckel, Seorang ahli biologi bangsa Jerman, murid Darwin, tahun 1866, yang menunjuk pada keseluruhan organisme atau pola hubungan antar organisme dan lingkunganya. ${ }^{9}$ Secara luas ekologi digunakan sebagai ilmu yang membahas hubungan timbal balik antar manusia dengan lingkungan. Sehingga yang menjadi inti permasalahan adalah hubungan antara manusia dan mahkluk hidup lain dalam lingkungannya.

Etika ekologi dalam perspektif teologi Kristen dapat diartikan ilmu tentang sikap dan tindakan moral manusia terhadap makhluk lain dalam lingkungannya yang mencerminkan, kebenaran, kebaikan, kasih dan keadilan sesuai dengan sifat-sifat Allah berdasarkan Alkitab. Penekanan utama dalam etika ekologi-teologis adalah sikap dan tindakan manusia terhadap lingkungan yang sesuai dengan kehendak Allah. Secara sederhana etika dapat didefinisikan sebagai: pertimbangan kelakukan atau tingkah laku yang bertanggung jawab terhadap Allah dan sesama manusia. ${ }^{10}$

Allah harus menjadi pusat etika ekologi. Artinya sikap dan tindakan manusia terhadap lingkungan hidup didasari atas kasih dan penghormatan kepada Allah. Kualitas spiritual individu mempengaruhi relasinya dengan Allah, sesama manusia, dan sesama makhluk hidup lain dalam lingkungannya. Sejalan dengan hal itu. Robert P. Borong membagi 2 jenis etika yaitu: Pertama, etika individual berbicara tentang kebaikan perilaku individu sehingga mencerminkan kualitas hidup pribadinya. Kedua, etika Sosial berbicara tentang perilaku seseorang dalam relasinya dengan sesamanya sehingga mencerminkan kualitas relasi

\footnotetext{
${ }^{6}$ J. Verkuyl, Etika Kristen: (Jakarta: BPK Gunung Mulia, 1993). 3

${ }^{7}$ Porong, Etika Bumi Baru. 142

${ }^{8}$ Tim Penyusun, Kamus Besar Bahasa Indonesia (Jakarta: Balai Pustaka, 1989). 251

${ }^{9}$ David Kinsley, Ecology and Religion: Ecological Spirituality in Cross-Cultural Perspective, Englewood Clifis, 1st ed. (USA: New Jersey, 1995). 20

${ }^{10}$ J. Douma, Kelakuan Yang Bertanggung Jawab, 1st ed. (Jakarta: BPK Gunung Mulia, 2000). 16 
yang seharusnya. ${ }^{11}$ Kedua jenis etika ini sangat ditentukan oleh kualitas spiritual seseorang. Sebab jikalau seseorang mengasihi Allah, dia akan mengaasihi dirinya dan sesamanya.

Etika teologi Kristen memiliki objek yang sama dengan etika secara umum, yaitu tingkah laku manusia. Akan tetapi tujuan yang hendak dicapainya sedikit berbeda, yaitu mencari apa yang seharusnya dilakukan manusia, dalam hal baik atau buruk, sesuai dengan kehendak Allah. ${ }^{12}$ Dari sudut iman Kristen etika lingkungan hidup bersifat "teosentris". Allah adalah pusat dari seluruh perilaku manusia terhadap alam semesta. Dan Allah telah menyatakan maksud dan kehendakNya di dalam Alkitab. Alkitab adalah firman Allah yang menjadi pedoman hidup orang percaya. Oleh karena itu ketika, etika ekologi dibangun, etika itu harus berdasarkan kebenaran Alkitab. Alkitab adalah sumber utama dari etika Kristen. Manusia yang merupakan representatif Allah di bumi diberikan kuasa dan kewenangan untuk mengolah alam semesta. Tetapi manusia adalah ciptaan Allah yang juga merupakan bagian integral dari alam semesta.

Mandat Allah Kepada manusia tertuang dalam Kejadian 1:28 "beranakcuculah, penuhilah bumi, taklukkan dan berkuasa atas ciptaan lain”, kemudian dalam Kejadian 2:15, "mengusahakan dan memelihara" taman Eden. Kejatuhan manusia dalam dosa tidaklah menyebabkan mandat itu diambil dari manusia. Karena Allah punya rencana keselamatan tidak hanya bagi manusia melainkan juga bagi alam semesta. Mandat yang selanjutnya adalah taklukanlah dan berkuasalah atas semua makhluk. Dua kata yang sering menjadi dasar legitimasi manusia bersikap sewenang-wenang terhadap alam semesta adalah kata "taklukkan dan berkuasalah". Kata taklukkanlah bukanlah berarti manusia diminta untuk menjajah alam semesta, melainkan menguasai untuk mengelola agar kebutuhan semua makhluk terpenuhi. Makna yang terkandung dalam bagian ayat tersebut adalah manusia harus bekerja dan bertindak memerintah atas nama Allah atas semua mahkluk. Jadi, tindakan manusia atas alam semesta adalah tindakan mengatur, mengelola, memelihara untuk keberlangsungan dan kesejahteraan semua mahkluk. Manusia diberi kuasa untuk melayani atas nama Allah.

Perintah memenuhi bumi dan menaklukkan bumi merupakan satu kesatuan yang sangat erat kaitannya dengan krisis lingkungan dewasa ini. Masalah demografi dan pengekploitasian alam saling berkaitan dalam mempercepat dan memperparah kerusakan alam ini. Penyimpangan mandat kebudayaan diakibatkan oleh dosa, namun juga mandat kebudayaan seringkali salah dimengerti. Keberadaan manusia yang lebih tinggi derajatnya

\footnotetext{
${ }^{11}$ Porong, Etika Bumi Baru. 142

${ }^{12}$ www.slideshare.net Abror Insani, Makalah Etika dan Moral Copyright@ 2021; SESAWI: Jurnal Teologi dan Pendidikan Kristen| 61
} 
membuat manusia merasa superior sehingga mahkluk lain hanyalah objek yang dapat diambil begitu saja untuk kebutuhan manusia. Penyimpangan mandat kebudayaan telah menyebabkan kerusakan alam yang fatal. Bumi berada diujung kehancuran. Namun Allah tidak akan membiarkan alam semesta yang sudah diciptakanNya rusak oleh dosa. Allah mempunyai rencana keselamatan yang holistik bagi seluruh ciptaan.

Latar Belakang teologis etika ekologi adalah penciptaan alam semesta. Tujuan Allah dalam penciptaan adalah:

1. Allah menciptakan langit dan bumi sebagai ungkapan kemuliaan, kemegahan dan kuasaNya (Mazmur 19:2)

2. Allah menciptakan langit dan bumi untuk menerima kembali kemuliaan dan hormat yang layak diterimaNya (Mazmur 98:7-8)

3. Allah menciptakan bumi supaya menyediakan sebuah tempat dimana maksud dan tujuanNya bagi umat manusia dapat digenapi. ${ }^{13}$

Mandat Allah kepada manusia harus dilaksanakan sesuai dengan tujuan penciptaan. Mandat Allah menjadi dasar teologis utama etika ekologi Kristen. Allah yang adalah pencipta, Pemilik, Pemegang, kekuasaan tertinggi di alam semesta memberikan mandat yang harus dijalankan oleh manusia. Allah berhak mengatur segala sesuatu menurut kehendakNya. Kedaulatan Allah atas setiap mahkluk adalah mutlak.

Pada waktu penciptaan, Allah melihat segala sesuatu yang telah diciptakanNya sungguh amat baik (tov meod). Walaupun diantara semua mahkluk, manusia diciptakan special, namun rancangan Allah berkaitan dengan kebenaran, keadilan, kebaikan dan kesejahteraan berlaku bagi semua mahkluk di alam semesta. Paul Enns menyatakan: "sebagai perantara Allah, Adam harus melaksanakan otoritas atas semua ciptaan, yaitu kehidupan tumbuh-tumbuhan dan binatang. Adam harus berkuasa atas ciptaan." 14 Semuanya itu dilakukan sebagai bentuk pengabdian dan ibadah kepada Allah.

Mandat Allah kepada manusia inilah yag harus menjadi dasar berpijak orang Kristen bersikap dan bertindak atas alam semesta. Karena sesungguhnya hak istimewah yang diberikan Allah ditujukan untuk kesejahteraan dan keberlangsungan semua mahkluk di bumi dan bukan hanya untuk manusia saja. Rencana Allah atas manusia sebagai pelaksana mandat terlihat dari bagaimana Allah menciptakan manusia berbeda dengan penciptaan mahkluk lain. Manusia diciptakan menurut gambar dan rupa Allah. Sebagai "gambar" Allah, manusia

\footnotetext{
13 "Alkitab Sabda" (Jakarta: Lembaga Alkitab Indonesia, n.d.).

${ }^{14}$ Paul Enns, Thel Moody Handbook Og Theology, 1st ed. (Malang: Literatur SAAT, 2003). 45 Copyright@ 2021; SESAWI: Jurnal Teologi dan Pendidikan Kristen| 62
} 
adalah "representatif Allah". Dalam diri manusia, Allah memberikan sifat-sifat Allah dalam bentuk, pengetahuan, kebenaran dan kekudusan, serta memiliki kuasa atas ciptaan lainnya. Semua sifat, pengetahuan yang Allah berikan merupakan karunia Allah kepada manusia untuk memelihara alam semesta. Sugiarto menyatakan: Tuhan tak menghendaki manusia hidup dalam kegelapan dan ketidaktahuan. Tuhan menghendaki supaya manusia mengenalnya dan Tuhan menghendaki supaya manusia menyelidiki segala yang dijadikan oleh Tuhan dan dengan demikian memperoleh pengetahuan dan pengertian atas jalan dan karya Tuhan. ${ }^{15}$

Pengetahuan dan pengertian atas jalan dan karya Tuhan merupakan hikmat yang dapat digunakan manusia untuk mengelola alam semesta. Celia Diane-Dummond menyatakan: "Manusia dicipitakan sebagai gambar Allah karena peranannya selaku penatalayan atau pelaksana atas ciptaan". ${ }^{16}$ Manusia bekerja degan kelengkapan karunia Allah. Sebagai "rupa" Allah menunjukan bahwa manusia "mempresentasikan dan menyerupai" Allah dalam batasan-batasan tertentu. Sehingga manusia tetaplah ciptaan yang terbatas, dan Allah tetaplah Pencipta yang tidak terbatas. Karena itu manusia dalam segala tindakannya tetaplah tunduk dan menghormati Allah. Kemampuan yang Allah berikan kepada manusia adalah kemampuan untuk bersekutu dengan Allah, kemampuan untuk melaksanakan kehendak Allah dan kemampuan untuk mengelola dan memelihara alam semesta.

Manusia sebagai pelaksana mandat, melaksanakan mandat sebagai bentuk pengakuan, penghormatan, ucapan syukur dan kasih kepada Allah sebagai Pencipta sekaligus Pemilik Alam Semesta. Norman L Geitser menyatakan, pandangan Kristen mengenai lingkungan timbul dari doktrin tentang pencipaan. Ajaran dalam agama Kristen timbul dua aspek penting mengenai lingkungan dalam Kristen yaitu kepemilikkan Allah dan kepelayanan manusia. ${ }^{17}$ Kepemilikan Allah atas alam semesta dan kepelayanan manusia menjadi dua tema utama dalam penciptaan. Allah adalah pemilik atas semua ciptaan manusia sebagai pelayan atas semua ciptaan.

Allah telah menunjukan kasihNya kepada manusia dan ciptaan lainnya. Sudah seharusnya, manusia pun mengasihi mahkluk lainnya sama seperti Allah. Menjadi gambar dan rupa Allah adalah hak istimewa manusia dari Allah, yang tentunya ada tujuan istimewa

\footnotetext{
${ }^{15}$ Sugiarto, Etika Kristen Dan Kebudayaan, 1st ed. (Jakarta: Badan Penerbitan Kristen, 2015). 64-65

${ }^{16}$ Celia Deane-Drummond, Theologi. 21.

${ }^{17}$ Norman L. Geitser, Etika Kristen, Pilihan Dan Isu, 1st ed. (Malang: Departemen Literatur SAAT, 2001). 386
} 
Allah di dalamnya. Millard J. Erickson menyatakan makna teologis dari penciptaan manusia adalah ciptaan yang berarti manusia tidak memiliki eksistensi sendiri, manusia memang berbeda dengan ciptaan lain, namun manusia tetaplah ciptaan, manusia memiliki kedudukan yang unik dalam ciptaan Allah, manusia terikat oleh ikatan persaudaraan dengan sesama dan manusia memiliki keterbatasan. ${ }^{18}$

Manusia diciptakan Allah dan di tempatkan di taman Eden. Di taman itu, manusia hidup bersama dengan ciptaan lain dalam satu lingkungan yang disebut lingkungan hidup. ${ }^{19}$ Manusia dapat berkomunikasi, berelasi, bersekutu dengan lingkungan sekitar. Ada kesatuan antara manusia dan mahkluk lain di lingkungannya. Ada hubungan kebergantungan antara satu dan lainnya. Manusia membutuhkan sumber daya alam untuk kebutuhan hidupnya, Di sisi lain, alam membutuhkan manusia untuk mengelola dan memelihara. Oleh karena itu, dapat dipahami di sini bahwa Allah sebagai Sang Pencipta menempatkan manusia sebagai ciptaan Tuhan yang hidup bersama mahkluk ciptaannya yang lain (lingkungan sekeliling manusia). ${ }^{20}$

Hubungan timbal balik dalam satu kesatuan sebagai sesama mahkluk hidup harus tetap terjalin dengan harmonis. Dibutuhkan hikmat dan pengertian, agar manusia dapat menjaga keseimbangan sikapnya terhadap alam. Manusia dapat mengambil sumber daya alam yang ada, namun juga manusia harus bisa memelihara keseimbangan ekosistem yang ada. ${ }^{21}$ Sehingga alam terpelihara, manusia terjamin kebutuhannya. Alam ini berfungsi ekumenis (untuk didiami) oleh seluruh ciptaan lainya. Alam ini rumah kita. Kata-kata "ekonomi", "ekumene", dan "ekologi” berakar dalam kata Yunani "oikos" yang artinya rumah. "Ekonomi" berarti menata rumah; itulah tugas pengelolaan kebutuhan hidup. "Ekumene" berarti mendiami rumah; itulah tugas penataan kehidupan yang harmonis. "Ekologi" berarti mengetahui atau menyelidiki rumah; itulah tugas memahami tanggung jawab terhadap alam. ${ }^{22}$ Sudah seharusnya tugas ekonomi dan ekologi berjalan seimbang. Millard J. Erickson menyatakan: kekeluargaan manusia dengan ciptaan lainnya memiliki dampak yang pasti. Arti dari istilah ekologi menunjukan manusia dan ciptaan lainnya ada

\footnotetext{
${ }^{18}$ Miliard J Erickson, Teologi Kristen Volume Dua, ed. 1, 1st ed. (Malang: Gandum Mas, 2012). 56-62

${ }^{19}$ Pada Umumnya lingkungan hidup di planet bumi dikategorikan dalam tiga kelompok dasar, yaitu lingkungan fisik (physical environment), Lingkungan biologis (biological environment) dan lingkungan Sosial (Sosial environment). Nursid Sumaatmadja, Studi Lingkungan Hidup, (Bandung: Penerbit Alami, 1989), hlm. 27.

${ }^{20}$ William Chang, Moral Lingkungan Hidup, 1st ed. (Yogyakarta: Kanisius, 2001). 46

${ }^{21}$ Ekosistem biasa juga dipahami sebagai hubungan timbal balik antara manusia dan lingkunganya, Imam Supardi, Lingkungan Hidup dan Kelestarian, (Bandung: Penerbitan Alumni, 1994) 8-13.

${ }^{22}$ Robert P. Borong, Etika Bumi. 198.
} 
dalam satu rumah tangga yang besar. ${ }^{23}$ Dimana manusia adalah kepala yang mengatur rumah tangga tersebut.

Tiap-tiap anggota rumah tangga harus hidup "rukun" agar rumah tangga itu sejahtera. Tentunya relasi yang harmonis dan selaras antara manusia dan ciptaan lain sangatlah menentukan kesejahteraan dan keberlangsungan semua mahkluk hidup termasuk manusia. Namun sayangnya, relasi yang harmonis itu telah hilang ketika manusia jatuh dalam dosa. Tanah menjadi terkutuk, dan manusia akan bersusah payah mencari rezeki di tanah yang terkutuk (Kejadian 3:17-18). Yesus Kristus adalah yang sulung dari semua ciptaan. Di dalam Dialah diciptakan segala sesuatu baik yang di sorga maupun di bumi. Ia terlebih dulu ada dari segala sesuatu. Dan segala sesuatu ada di dalam Dia. Karena seluruh kepenuhan Allah diam di dalam Dia, dan Ia memperdamaikan segala sesuatu dengan diriNya, baik yang ada di bumi, maupun yang ada di sorga (Kolose 1:15-20).

\section{Sikap Etis Ekologi Teologi Kristen}

Manusia adalah mahkluk yang bermoral, tahu membedakan mana yang benar dan salah. Stephen Tong mengatakan: Allah menciptakan manusia dengan sifat moralitas, artinya manusia adalah mahkluk bermoral. ${ }^{24}$ Etika ekologi-teologis adalah petunjuk sikap dan perilaku moral manusia terhadap lingkungan hidup. Ada beberapa sikap etis ekologi-teologis yang berdasarkan mandat kebudayaan dalam penciptaan:

a. Menghormati Allah Pencipta Alam Semesta

Sikap etis-teologis yang pertama adalah menghormati Allah yang adalah Pencipta alam semesta. Sikap menghormati dapat ditunjukkan dengan selalu mempunyai keinginan untuk menaati Allah. Menyadari bahwa Allahlah yang empunya alam semesta dan segala yang ada di dalamnya termasuk manusia. Sikap yang demikian akan membawa manusia pada kesadaran, bahwa manusia tidak mempunyai hak mutlak atas alam semesta melainkan manusia adalah representatif Allah yang harus tetap tunduk kepada Allah yang adalah pencipta.

Tugas pengelolaan alam semesta dilakukan manusia tidak hanya untuk memenuhi kebutuhan manusia dan kesejahteraan hidup mahkluk lain, namun harus sebagai bentuk pengabdian, rasa syukur dan kasih kepada Allah. Hak istimewa sebagai kepala atas seluruh ciptaan adalah sebuah kepercayaan. Manusia bukanlah pemilik melainkan penatalayan atas

\footnotetext{
${ }^{23}$ Erickson, Teologi Kristen Volume Dua. 25

${ }^{24}$ Stephen Tong, Peta \& Teladan Allah, 1st ed. (Jakarta: Lembaga Reformed Injili Indonesia, 1990). 24 Copyright@ 2021; SESAWI: Jurnal Teologi dan Pendidikan Kristen| 65
} 
alam semesta. Jika hal ini disadari, maka tindakan sewenang-wenang terhadap alam semesta dapat dihindari,

\section{b. Melakukan Tugas Penatalayanan Atas Alam Semesta}

Kesadaran diri manusia sebagai pelaksana tugas penatalayanan alam semesta membuat manusia memiliki sikap sebagai seorang kepala, pemimpin yang mengayomi seluruh mahkluk hidup yang ada dalam pengelolaannya. Seorang pemimpin alam semesta tidak hanya memperhatikan mahkluk hidup tertentu saja, melainkan kepentingan seluruh mahkluk hidup termasuk dirinya. Menjadi seorang penatalayan alam semesta adalah seorang pemimpin yang melayani. Adapun Karakteristik yang harus dimiliki seorang penatalayan alam semesta adalah:

- Bekerja segiat-giatnya bagi Allah yang adalah pemilik kehidupan semua mahkluk.

- Bekerja segiat-giatnya bagi kesejahteraan dan keberlangsungan hidup diri sendiri dan sesama manusia.

- Bekerja segiat-giatnya bagi kesejahteraan dan keberlangsungan mahkluk hidup di alam semesta.

- Bersikap jujur, adil, benar dan kasih terhadap semua mahkluk

c. Menghargai Mahkluk hidup Di Alam Semesta

Terhadap segala makhluk ciptaannya, seharusnya manusia bersikap menghargai dan memperlakukannya sesuai dengan nilai yang terkandung di dalam makhluk ciptaannya. Solidaritas terhadap alam semesta perlu dibangun. Ketika manusia membutuhkan makan dan minum, dia pun harus ingat, bahwa mahkluk lain pun membutuhkan makanan untuk hidup. Sikap yang tidak egois manusia akan membuat hubungan manusia dengan alam menjadi selaras. Kerja sama antara manusia dan lama dapat berjalan dengan baik. Mengingat manusia adalah kodrat sosial, maka kebanyakan tindakan manusiawi mencakup kerja sama dan hubungan manusia dengan segala ciptaan Tuhan. ${ }^{25}$

d. Tindakan Etis Ekologi Teologi Kristen

Tindakan etis ekologi-teologis yang tepat dapat membantu penyelamatan bumi yang sudah diujung kehancuran. Kenyataannya, manusia yang sekarang lebih banyak mengembangkan pengetahuan, teknologi dan pembangunan ekonomi berdasarkan naluri dan rasio yang sarat akan kepentingan pribadi atau kelompok. Robert P. Borong menyatakan:

\footnotetext{
${ }^{25}$ Martin Lukito Sinaga, Menembus Ciptaan: Konferensi Tingkat Tinggi Bumi Rio: Tantangan Bagi Gereja Gereja, 1st ed. (Jakarta: BPK Gunung Mulia, 1994). 85
}

Copyright@ 2021; SESAWI: Jurnal Teologi dan Pendidikan Kristen| 66 
"Sejarah memperlihatkan kepada kita bahwa selama manusia modern mengandalkan kekuatan rasio atau ilmu pengetahuan dan teknologi sambil melupakan kekuatan etika dan moral, maka ia terus menuju kehancuran." ${ }^{26}$

Rasionalisme memberikan pengaruh buruk pada sikap dan perilaku manusia terhadap alam. Tindakan rasional yang tidak terkontrol membawa manusia pada kesombongan dan keserakahan. Manusia begitu mengagungkan dirinya sebagai mahkluk yang spesial yang berakal budi dan berkuasa atas alam. Harus ada solusi yang tepat dan tindakan yang tepat untuk mengatasi krisis ekologi. Usulan tindakan etis ekologi-teologis adalah sebagai berikut:

\section{a. Tindakan Evaluatif}

Dalam Kamus Besar Bahasa Indonesia kata "evaluatif" diartikan: yang berhubungan dengan evaluasi; bersifat evaluasi. ${ }^{27}$ Tindakan evaluatif yang dimaksud disini adalah manusia berusaha menganalisa, memeriksa, mengoreksi dan menemukan sikap dan tindakannya yang keliru terhadap alam. Menyadari kekeliruan dan menerapkan sikap baru terhadap lingkungannya. Untuk mengatasi krisis ekologi, dibutuhkan lebih dari sekedar spiritualitas yang peduli pada lingkungan hidup; untuk mengatasi krisis ekologi dibutuhkan perubahan radikal dalam gaya hidup masyarakat modern yang konsumtif, pengambilan keputusan politik yang berpihak pada keselamatan lingkungan. ${ }^{28}$ Kesadaran spiritual tanpa pertobatan adalah sia-sia. Dibutuhkan tindakan nyata, berpaling dari sikap yang mementingkan diri sendiri, sikap yang menghalalkan segala cara untuk memenuhi kebutuhan hidup sehingga kerusakan ekologi dapat teratasi.

Tindakan evaluatif dapat berupa negatif atau positif. Evaluatif negatif adalah koreksi terhadap tindakan-tindakan destruktif terhadap lingkungan untuk pencegahan kerusakan lanjutan. Kerusakan lingkungan hidup terjadi karena adanya tindakan yang menimbulkan perubahan langsung atau tidak langsung sifat fisik dan/atau hayati sehingga lingkungan hidup tidak berfungsi lagi dalam menunjang pembangunan berkelanjutan. Kerusakan lingkungan hidup terjadi karena adanya tindakan yang menimbulkan perubahan

\footnotetext{
${ }^{26}$ Robert P. Borong, Etika Bumi.3

${ }^{27}$ Tim Penyususun, Kamus Besar. 272.

${ }^{28}$ Irene Ludji, Spirirtualitas Lingkungan Hidup: Respon Iman Kristen Terhadap Krisis Ekologi, hlm. 71. File://E:/Download/Mo1307\%20(4).pdf
} 
langsung atau tidak langsung sifat fisik dan/atau hayati sehingga lingkungan hidup tidak berfungsi lagi dalam menunjang pembangunan berkelanjutan. ${ }^{29}$

Tindakan evaluatif postif menemukan tindakan-tindakan positif terhadap lingkungan yang dapat dikembangkan. Contohnya pengolahan limbah rumah tangga yang dapat dijadikan pupuk, sampah plastik yang dapat dimanfaatkan, daur ulang sampah, dan lain-lain. Tindakan-tindakan ini perlu dikembangkan lebih lanjut agar menghasilkan karya yang kreatif dan inovatif yang tidak hanya menguntungkan bagi manusia saja melainkan bagi lingkungan hidup.

Gereja harus mampu mengevaluasi diri dan jemaat, baik positif maupun negatif. Gereja harus berani dan jujur mengoreksi, kemungkinan ada program-program gereja yang tidak berpihak pada lingkungan hidup bahkan merusak lingkungan. Kemungkinan ada jemaat yang melakukan pelanggaran hukum berkaitan dengan lingkungan hidup, atau ada jemaat yang sengaja merusak lingkungan hidup untuk memenuhi kebutuhannya dan lain-lain. Jikalau ditemukan tindakan destruktik terhadap alam, gereja harus berani menegur dan menasehati, memperbaiki kesalahan gereja dan warga gerejanya. Gereja harus berpaling secara radikal dari perbuatan yang sewenang-wenang terhadap alam semesta.

Untuk evaluasi positif. Gereja berusaha menemukan tindakan-tindakan positif gereja dan jemaat yang tidak saja bernilai ekonomi tetapi juga bernilai ekologi. Kemudian mengembangkan potensi ekonomi jemaat dengan melakukan pelatihan ketrampilan pengolahan limbah yang bernilai ekonomi, yang dengan sendirinya ikut menjaga kelestarian lingkungan hidup.

Pengolahan limbah rumah tangga dan industri akan memberi dampak besar bagi lingkungan hidup. Karena setiap harinya rumah tangga menghasilkan sampah, demikian juga industri. Jika limbah sampah tersebut diolah secara kreatif, maka akan mendatangkan keuntungan ganda. Alam terpelihara hidup manusia tercukupi. Gereja harus bersedia belajar sebanyak mungkin ketrampilan yang mendukung program penyelamatan bumi. Tindakan Preventif

Kata "preventif" dalam Kamus Besar Bahasa diartikan: "bersifat mencegah (supaya jangan terjadi apa-apa)". ${ }^{30}$

\footnotetext{
${ }^{29}$ Dampak Kerusakan Lingkungan Bagi Manusia, www.changeyourlife.co.id/index.php/-news diunduh tanggal 18 Oktober 2015

${ }^{30}$ Tim Penyusun, Kamus Besar. 788
}

Copyright@ 2021; SESAWI: Jurnal Teologi dan Pendidikan Kristen| 68 
Sedangkan W.J.S. Poerwadarminta memberikan dua pengertian, yaitu: "1. Bersifat mencegah (supaya jangan terjadi), 2. Penahanan di penjara untuk sementara (selama menanti keputusan hakim). ${ }^{31}$ Istilah preventif yang dimaksud dalam pembahasan ini adalah arti yang pertama yaitu bersifat mencegah.

Tindakan preventif merupakan usaha menemukan upaya-upaya pencegahan yang dapat dilakukan agar kerusakan lingkungan hidup tidak terjadi atau bertambah parah. Bambang Tri Bawono dan Anis Mashdurohatun menyatakan: Tindakan preventif merupakan tindakan yang berorientasi ke depan yang sifatnya strategis dan merupakan rencana aksi jangka menengah dan jangka panjang, namun harus dipandang sebagai tindakan yang mendesak untuk segera dilaksanakan. ${ }^{32}$ Selanjutnya Fitria menuliskan: Upaya preventif dalam rangka pengendalian dampak lingkungan hidup perlu dilaksanakan dengan meggunakan secara maksimal instrumen pengawasan dengan memperhatikan syarat-syarat yang tercantum di dalam perijinan. ${ }^{33}$

Berdasarkan pengertian di atas, maka tindakan preventif yang dapat dilakukan gereja adalah:

1. Membina dan memperlengkapi anggota-anggota gereja secara doktrinal pengajaran yang berkaitan landasan teologis etika ekologi, agar jemaat memiliki kesadaran dan pengetahuan bagaimana harus menjaga kebersihan dan bersikap dan bertindak benar dalam kelestarian lingkungan hidup mulai dari lingkungan tempat tinggal.

2. Memperlengkapi anggota gereja dengan ketrampilan-ketrampilan yang menguntungkan sekaligus mencegah terjadinya kerusakan lingkungan hidup dengan memaksimalkan lahan yang ada, antara lain: budi daya tanaman, budi daya ikan, kebun bunga dan sayur-sayuran, dan lain-lain.

3. Bekerja sama dengan masyarakat setempat melakukan upaya-upaya pencegahan pencemaran lingkungan, kepunahan flora dan fauna, pengolahan limbah rumah tangga, daur ulang, penghijauan, dan lain-lain.

\footnotetext{
${ }^{31}$ W. J. S. Poerwadaminta, Kamus Umum. 278.

${ }^{32}$ Anis Mashdurohatun Bambang Tri Bawono, "Penegakan Hukum Pidana Di Bidang Illegal Logging Bagi Kelestarian Lingkungan Hidup Dan Upaya Penanggulangannya,” Jurnal Hukum 26, no. 2 (2011): 606, http://lppm-unissula.com/jurnal.unissula.ac.id/index.php/jurnalhukum/article/view/211.

${ }^{33}$ Fitria Fitria, "Penegakan Hukum Administrasi Terhadap Analisis Mengenai Dampak Lingkungan(AMDAL) Berdasarkan Undang-Undang 32 Tahun 2009 Di Kota Jambi,” Jurnal Ilmu Hukum Jambi (JIH) 2, no. 1 (2015): 35, https://www.neliti.com/publications/43311/penegakan-hukum-administrasiterhadap-analisis-mengenai-dampak-lingkunganamdal-b.
} 
4. Melaporkan kepada pihak terkait, jika menemukan ada tindakandestruktif terhadap lingkungan sekitar. Mengusulkan kepada pemerintah untuk melakukan peninjauan kembali apabila menemukan peraturan perundang-undangan yang tidak berpihak pada lingkungan hidup.

\section{b. Tindakan Rehabilitasi}

Istilah "rehabilitasi" dalam Kamus Besar Bahasa Indonesia diartikan: "1. Pemulihan kepada kedudukan (keadaan) yang dahulu (semula); 2. Perbaikan anggota tubuh yang cacat dan sebagainya atas individu supaya menjadi manusia yang berguna dan memiliki tempat di masyarakat". ${ }^{34}$ Arti yang digunakan dalam pembahasan ini adalah arti yang pertama yaitu pemulihan kepada kedudukan atau keadaan semula. Tindakan rehabilitasi merupakan usaha menemukan tindakan-tindakan yang tepat untuk memperbaiki lingkungan hidup yang telah rusak. Rehabilitasi dimulai dengan mengumpulkan data-data yang berkaitan dengan kerusakan lingkungan yang mana yang dapat diperbaiki dan mana yang bersifat permanen. Lingkungan hidup yang rusak dan masih dapat diperbaiki menjadi fokus utama rehabilitasi. Selanjutnya, menemukan tindakan yang tepat untuk melaksanakan rehabilitasi supaya tujuan rehabilitasi dapat tercapai dan bermanfaat bagi manusia dan lingkungan. Rehabilitasi dilakukan dengan cara paling sedikit meliputi:

1. identifikasi lokasi, penyebab, dan besaran kerusakan Lingkungan Hidup:

2. pemilihan metode rehabilitasi;

3. penyusunan rencana dan pelaksanaan rehabilitasi; dan

4. penyusunan dan penyampaian laporan pelaksanaan rehabilitasi terhadap Kerusakan Lingkungan Hidup kepada Menteri, gubernur, dan bupati/wali kota. ${ }^{35}$

Lingkungan hidup yang dapat direhabilitasi adalah salah satunya adalah lahan kritis. Lahan kritis merupakan salah satu luasan area yang tidak produktif yang mana tingkat produktivitas/kesuburan lahan sangat rendah, jumlah produksi yang diterima jauh lebih sedikit daripada biaya pengelolaannya. ${ }^{36}$ Rehabilitasi lahan merupakan suatu usaha memperbaiki, memulihkan kembali dan meningkatkan kondisi lahan yang rusak agar dapat

\footnotetext{
${ }^{34}$ Tim Penyusun, Kamus Besar. hlm. 826.

35 imahfudh, "Tata Cara Pemulihan Fungsi Lingkungan Hidup Sesuai PP 101 Tahun 2014," Wordpress, last modified 2015, accessed June 3, 2021, https://imammahfudh.wordpress.com/2015/02/16/tata-cara-pemulihanfungsi-lingkungan-hidup-sesuai-pp-101-tahun-2014/.

${ }^{36}$ Helen Tiorita, "Rehabilitasi Lahan Kritis Dengan Sistem Agroforestry Oleh," Jurnal Lingkungan Hidup, last modified 2012, accessed June 3, 2020, https://uwityangyoyo.wordpress.com/2012/09/02/rehabilitasi-lahankritis-dengan-sistem-agroforestry-oleh-helen-tiorita/.
} 
berfungsi secara optimal baik sebagai unsur produksi, media pengatur tata air, maupun sebagai unsur perlindungan alam dan lingkungannya. ${ }^{37}$

Peranan gereja dalam rehabilitasi lingkungan hidup dapat dimulai dari lingkungan gereja dan sekitarnya. Gereja dapat berusaha menemukan lahan kritis, Tempat pembuangan sampah yang terlantar, saluran-saluran air yang tersumbat, dan lain-lain. Kemudian dapat memikirkan cara tepat untuk melakukan rehabilitasi, area yang rusak dan tidak berfungsi dapat direhabilitasi menjadi area yang sejuk dan bermanfaat.

c. Tindakan Kerja Sama

Kerja sama antara manusia dan alam semesta untuk bisa memenuhi kebutuhan masing-masing secara berkelanjutan. Tindakan kerja sama berusaha menemukan tindakantindakan yang menguntungkan kedua belah pihak, baik bagi manusia maupun mahkluk hidup lain di masa sekarang maupun akan datang. Setiap mahkluk dapat bekerja sama dan bersikap kooperatif satu sama lain, yang dikenal dengan istilah biologi "simbiosis metualisme". ${ }^{38}$

Tindakan kerja sama hendaknya menguntungkan kedua belah pihak dimana, tidak ada pihak yang dikorbankan. Manusia boleh mengambil dan menikmati hasil alam secara proporsional, kemudian mengupayakan tindakan perlindungan dan pemeliharaan. Keseimbangan sikap manusia terhadap alam yang akan menjamin kerja sama antara manusia dan alam terjalin harmonis. Manusia dapat menyatu dengan alam. Taman eden akan tercipta kembali.

Bagi gereja, tindakan kerja sama merupakan tugas gereja di bumi, sampai Allah memulihkan segala sesuatunya. Gereja seharusnya dapat lebih serius mengusahakan dan menjalankan misi pemulihan ciptaan yang telah rusak ini. ${ }^{39}$ Gereja tidak boleh lagi berpangku tangan apalagi lepas tangan terhadap masalah lingkungan hidup. Keperdulian gereja terhadap lingkungan hidup sedang dinantikan oleh Allah sebagai Pencipta dan mahkluk hidup lain sebagai "anggota keluarga" alam semesta. Winfrid Prayogi menyatakan: Gereja secara aktif dan kreatif mengambil bagian dalam mewujudkan perdamaian, keadilan dan keutuhan ciptaan di Indonesia. Disamping itu Gereja juga mengambil bagian dalam usaha mencegah

\footnotetext{
${ }^{37}$ Ibid

${ }^{38}$ Simbiosis adalah bentuk interaksi antara dua mahkluk hidup yang berlainan jenis. Makhluk hidup yang melakukan simbiosis disebut simbion. Simbiosis mutualisme terjadi apabila terdapat hubungan yang saling menguntungkan terhadap dua jenis individu yang berbeda. Contoh Simbiosis Mutualisme adalah hubungan lebah dan bunga. Lebah mendapatkan madu dari bunga, sedangkan Bunga dibantu penyerbukannya oleh lebah. www.pengertianahli.com/2013/11/pengertian-simbiosis-mutualisme.html\#

${ }^{39}$ Ferry Y. Mamahit, Apa hubungan Porong. 24
} 
segala hal yang merongrong dan merendahkan harkat dan martabat manusia serta segala yang merusak lingkungan alam Indonesia. ${ }^{40}$

Gereja yang harus bergerak untuk menyerukan: "selamatkanlah bumi dari kehancuran". Gereja segera membuat program-program yang perduli dengan lingkungan hidup, memberikan edukasi ekologi-teologis kepada jemaat sehingga jemaat dapat terlibat dalam penyelamatan lingkungan hidup. Gereja harus melibatkan warga gereja untuk aktif dalam upaya pelestarian lingkungan hidup.

Christian Onesimus menyatakan hal real apa yang dapat dilakukan oleh gereja adalah:

1) Meningkatkan kesadaran masyarakat akan bahaya pengrusakan alam dan mengajak asyarakat untuk melesetarikan alam sekitar kita.

2) Melakukan penghijauan. Penghijauan bisa dilakukan di dalam lingkungan gereja ataupu di luar lingkungan gereja. Upaya-upaya penanaman seribu pohon dengan bibit cepat tumbuh, bisa mengurangi efek yang buruk terhadap lingkungan kita.

3) Melakukan penghematan. Mengurangi penggunaan kertas akan berdampak bagi industriindustri pulp yang menggunakan katu dalam membuat kertas (paper-less). ${ }^{41}$

Gereja tidak hanya perlu melaksanakan pendidikan lingkungan dan pengkajian permasalahan lingkungan, tetapi harus mempraktikkannya melalui kegiatan dan tindakan yang nyata sebagai wujud dari gerakan cinta lingkungan. Gereja-gereja dapat memilih dan menentukan sendiri bentuk kegiatan yang cocok dan realistik untuk dilakukan, misalnya dengan membersihkan sungai dari sampah pencemar atau menanam pohon di tanah gersang.

Gerakan gereja ini dapat berbentuk advokasi atau pembelaan terhadap lingkungan yang dikorbankan secara semena-mena untuk kepentingan manusia. Misalnya pencemaran sungai oleh pembangunan industri yang tidak memperdulikan ekosistem.

Semoga gereja cepat tanggap akan kondisi lingkungan hidup disekitarnya. Gereja adalah saksi Allah di dunia. Gerejalah yang harus paling depan berdiri menyuarakan suara kenabian untuk penyelamatan lingkungan hidup, karena gerejalah memegang kuasa untuk melakukan mandat kebudayaan dalam penciptaan. Dan gerejalah yang telah dilepaskan dari ikatan dosa, dipulihkan dan dikuduskan Allah. Gereja mempunyai segala bentuk kelengkapan perbuatan baik yang datangnya dari Allah.

\footnotetext{
${ }^{40}$ Winfrid Prayogi, "Mencari Esensi Dan Misi Gereja Dalam Konteks Indonesia Awal Abad 21," Veritas 5, no. 2 (2000): 123, http://repository.seabs.ac.id/handle/123456789/9.

${ }^{41}$ Christian Onenimus, Makalah Etika Ekologi..., hlm. 6.
} 


\section{KESIMPULAN}

Manusia diciptakan Allah dari debu tanah. Ketika mati, manusia akan kembali menjadi debu tanah (Kejadian 2:7; 3:19). Pada hakekatnya, manusia berasal dari alam, tinggal di alam dan kembali ke alam. Ada kesatuan antara manusia dengan alam baik waktu hidup maupun mati. Oleh karena itu, sudah seharusya manusia menyatu dengan alam baik hidup atau mati. Setelah penciptaan, Allah menempatkan manusia di taman Eden untuk memelihara dan mengelola taman itu (Kejadian 2:15).

Pengelolaan manusia atas alam adalah pengelolaan yang melayani. Dimana manusia sebagai kepala atas ciptaan memperhatikan kebutuhan ciptaan lain yang dipimpinnya. Jadi jikalau ada "anggota" alam semesta "sakit", maka sebagai kepala, manusia harus berusaha "menyembuhkannya". Jikalau ada anggota yang lapar, ia harus memberi makan. Ini berarti keberlangsungan seluruh ciptaan Allah yang ada di alam semesta ada dalam tanggung jawab manusia. Manusia dan ciptaan lain ada dalam satu "rumah" (oikos) yang besar yaitu alam semesta, dimana manusia adalah "kepala" dari seluruh ciptaan.

\section{DAFTAR PUSTAKA}

Bambang Tri Bawono, Anis Mashdurohatun. "Penegakan Hukum Pidana Di Bidang Illegal Logging Bagi Kelestarian Lingkungan Hidup Dan Upaya Penanggulangannya.” Jurnal Hukum 26, no. 2 (2011): 606.

http://lppmunissula.com/jurnal.unissula.ac.id/index.php/jurnalhukum/article/view/211. Chang, William. Moral Lingkungan Hidup. 1st ed. Yogyakarta: Kanisius, 2001.

Douma, J. Kelakuan Yang Bertanggung Jawab. 1st ed. Jakarta: BPK Gunung Mulia, 2000. Enns, Paul. Thel Moody Handbook Og Theology. 1st ed. Malang: Literatur SAAT, 2003. Erickson, Miliard J. Teologi Kristen Volume Dua. Edited by 1. 1st ed. Malang: Gandum Mas, 2012.

Fitria, Fitria. "Penegakan Hukum Administrasi Terhadap Analisis Mengenai Dampak Lingkungan(AMDAL) Berdasarkan Undang-Undang 32 Tahun 2009 Di Kota Jambi.” Jurnal Ilmu Hukum Jambi (JIH) 2, no. 1 (2015): 35.

https://www.neliti.com/publications/43311/penegakan-hukum-administrasi-terhadapanalisis-mengenai-dampak-lingkunganamdal-b.

Geitser, Norman L. Etika Kristen, Pilihan Dan Isu. 1st ed. Malang: Departemen Literatur SAAT, 2001.

Imahfudh. "Tata Cara Pemulihan Fungsi Lingkungan Hidup Sesuai PP 101 Tahun 2014.” Wordpress. Last modified 2015. Accessed June 3, 2021. 
https://imammahfudh.wordpress.com/2015/02/16/tata-cara-pemulihan-fungsilingkungan-hidup-sesuai-pp-101-tahun-2014/.

J. Verkuyl. Etika Kristen: Seksuil. Jakarta: BPK Gunung Mulia, 1993.

Kinsley, David. Ecology and Religion: Ecological Spirituality in Cross-Cultural Perspective, Englewood Clifis. 1st ed. USA: New Jersey, 1995.

Penyusun, Tim. “Kamus Besar Bahasa Indonesia.” In Kamus, 735. 2nd ed. Jakarta: Badan Pengembangan dan Pembinaan Bahasa Kementerian Pendidikan dan Kebudayaan Republik Indonesia, 2016.

Porong, Robert P. Etika Bumi Baru. 1st ed. Jakarta: BPK Gunung Mulia, 2003.

Prayogi, Winfrid. "Mencari Esensi Dan Misi Gereja Dalam Konteks Indonesia Awal Abad 21." Veritas 5, no. 2 (2000): 123. http://repository.seabs.ac.id/handle/123456789/9. Sinaga, Martin Lukito. Menembus Ciptaan: Konferensi Tingkat Tinggi Bumi Rio: Tantangan Bagi Gereja Gereja,. 1st ed. Jakarta: BPK Gunung Mulia, 1994.

Sugiarto. Etika Kristen Dan Kebudayaan. 1st ed. Jakarta: Badan Penerbitan Kristen, 2015.

Tim Penyusun. Kamus Besar Bahasa Indonesia. Jakarta: Balai Pustaka, 1989.

Tiorita, Helen. "Rehabilitasi Lahan Kritis Dengan Sistem Agroforestry Oleh.” Jurnal Lingkungan Hidup. Last modified 2012. Accessed June 3, 2020. https://uwityangyoyo.wordpress.com/2012/09/02/rehabilitasi-lahan-kritis-dengansistem-agroforestry-oleh-helen-tiorita/.

Tong, Stephen. Peta \& Teladan Allah. 1st ed. Jakarta: Lembaga Reformed Injili Indonesia, 1990.

“Alkitab Sabda.” Jakarta: Lembaga Alkitab Indonesia, n.d.

“Materi-Materi Kuliah.” Blogspot. Last modified 2012. https://umnuu.blogspot.com/2012/12/makalah-iad-prinsip-ekologi.html. 